\title{
COISA JULGADA INCONSTITUCIONAL: OS EFEITOS DO CONTROLE DIFUSO DE CONSTITUCIONALIDADE NO NOVO CPC E A SEGURANÇA JURÍDICA
}

\author{
THE INCONSTITUCIONAL RES JUDICATA: THE EFFECTS OF \\ JUDICIAL REVIEW IN THE NEW CPC AND THE LEGAL CERTAINTY
}

\author{
David Abdalla Pires Leal ${ }^{1}$ \\ Giovanni Bonato ${ }^{2}$
}

\section{RESUMO}

Este artigo busca avaliar o art. 525, $\S \S 12$ e15, do novo CPC, que introduziu nova hipótese de cabimento da ação rescisória fundada em declaração de inconstitucionalidade pelo STF que tenha abordado lei que serviu de base para a decisão rescindenda, abrindo-se novo prazo para o ajuizamento desta medida excepcional a partir da declaração desta Corte Suprema. A análise se dá em cotejo desta norma com os princípios da segurança jurídica, especialmente em face da sua vertente da inafastabilidade da jurisdição, passando pela discussão acerca da teoria da abstrativização do controle difuso para, ao final, avaliar a sua constitucionalidade.

Palavras-chave: Controle de constitucionalidade; Ação Rescisória; Segurança Jurídica; Coisa Julgada; e .

\begin{abstract}
This paper seeks to evaluate the art. $525, \S \S 12$ and 15 of the 2015 Code of Civil Procedure, which introduced new hypothesis of the suitability of rescission action founded on unconstitutionality declarated by the Supreme Court that has addressed the legislative foundation that formed the basis for the decision who seeks to terminate, opening new deadline for the filing of this exceptional measure from the statement of the Supreme Court. The analysis takes place in collating this standard with the principles of legal certainty, through the discussion of theory of judicial review to, at the end, assess its constitutionality.
\end{abstract}

Keywords: Judicial Review; Rescissory Action; Legal Certainty.

\footnotetext{
${ }^{1}$ Mestrando em Direito e Instituições do Sistema de Justiça pela Universidade Federal do Maranhão UFMA, Maranhão (Brasil). E-mail: david_abdalla@yahoo.com.br

2 Doutor em Direito Processual Civil pela Università degli Studi do Roma e Universidade de Paris, professor-pesquisador na Universidade de Paris Ouest Nanterre La Défense. Professor visitante pela Universidade Federal de Maranhão - UFMA, Maranhão (Brasil). E-mail: giovannibonato @ virgilio.it
} 


\section{INTRODUÇÃO}

O direito a segurança é protegido no ocidente desde a revolução francesa e permanece sendo reconhecido como direito fundamental no âmbito internacional desde a década de 1940 até os dias de hoje.

No direito brasileiro o tratamento constitucional da matéria não é divergente do que ocorre no exterior, uma vez que a carta magna brasileira também considera como fundamental o direito à tutela jurisdicional e aloca, neste mesmo patamar, a proteção ao direito adquirido, ao ato jurídico perfeito e à coisa julgada que, juntos, dão contornos jurídicos ao direito fundamental à segurança, como se observa através do art. $5^{\circ}$, XXXVI da Constituição da República (BRASIL, 1988).

Nesse diapasão, a legislação infraconstitucional nacional estabelece o que se considera como coisa julgada e, ainda que de forma deveras sucinta, formata as hipóteses excepcionais que autorizam a sua desconstituição, bem como os mecanismos processuais necessários para este desiderato.

É sob a perspectiva do direito à segurança jurídica através da estabilidade da jurisdição, que este trabalho busca avaliar os efeitos do controle difuso de constitucionalidade exercido pelo STF sobre a decisão judicial transitada em julgado, de acordo com o disposto no novo código de processo civil (BRASIL, 2015).

Para tanto, incialmente serão abordados a origem e o conceito de coisa julgada e a sua diferenciação dos efeitos da sentença. Em seguida tratar-se-á da decisão judicial transitada em julgado assentada sobre fundamento declarado inconstitucional, ou seja, a denominada coisa julgada inconstitucional.

A possibilidade de revisão desta espécie de julgado por meio do disposto no art. $525, \S \S 12$ e 15, do novo código de processo civil (BRASIL, 2015) será abordada sob a perspectiva dos efeitos dos julgamentos em controle difuso de constitucionalidade do STF sobre os demais processos.

Em seguida e, por fim, proceder-se-á uma avaliação sobre a possibilidade de ajuizamento da ação rescisória por meio dos preceitos constantes nos $\S \S 12$ e 15, do art. 525, do novo código de processo civil sob a perspectiva temporal, especialmente no que se refere à necessidade de uma aplicação deste dispositivo consentânea com os 
princípios constitucionais da intangibilidade da coisa julgada como expressão do direito fundamental à segurança jurídica e como prestígio a uma jurisdição efetiva e estável, sem olvidar da necessidade de observância ao princípio da constitucionalidade.

\section{COISA JULGADA E OS EFEITOS DA SENTENÇA}

$\mathrm{O}$ direito fundamental à segurança jurídica ${ }^{3}$ encontra proteção no ocidente desde a Declaração dos Direitos do Homem e do Cidadão da França (FRANÇA, 1789) que estabelecia em seu artigo segundo: "A finalidade de toda associação política é a conservação dos direitos naturais e imprescritíveis do homem. Esses direitos são a liberdade, a propriedade, a segurança e a resistência à opressão".

$\mathrm{O}$ direito à tutela jurisdicional ${ }^{4}$ também é reconhecido no âmbito internacional através dos arts. $8^{\circ}$ e 10, da Declaração dos Direitos do Homem (ONU, 1948).

É sobre estes alicerces que se encontra a coisa julgada que, entretanto, é instituto constantemente debatido nos campos doutrinário e jurisprudencial brasileiro, posto que a sua definição e qualidades importam em consequências para a esfera jurídica das partes e, eventualmente, de terceiros, a depender das características dos direitos vindicados e da modalidade de atividade jurisdicional desempenhada pelo Estado.

Inobstante a sua importância, para GRECO (2003), a coisa julgada no Brasil é instituto muito frágil e esta característica deriva de vários fatores, dentre eles: a) das questões históricas originadas da tradição romano-germânica, tendo como exemplo a criação da ação rescisória pelo direito brasileiro que não encontra paralelos em nenhum outro sistema jurídico no mundo; b) do paternalismo herdado da colonização portuguesa; c) da necessidade de correção dos erros de uma justiça sem credibilidade; e

\footnotetext{
${ }^{3}$ Sobre a matéria é importante trazer à baila os ensinamentos de NIEVA-FENOLL (2016, p. 135): "a segurança jurídica requer que sobre cada assunto somente se possa decidir apenas uma única vez. A jurisdição existe para dar estabilidade e segurança às relações humanas conflitivas”.

${ }^{4}$ A lição de NIEVA-FENOLL (2016, p. 141-142), mais uma vez, é importante para o entendimento da matéria: "a coisa julgada é elemento distintivo da atividade jurisdicional, isto é, que não pode encontrarse o conceito de coisa julgada em outro âmbito do poder político que não seja o judicial. Com essa base de pensamento também se chegou a dizer que a coisa julgada era um fundamento da Justiça ou um elemento fundamental do Direito processual, ou uma característica indispensável da jurisdição, um efeito necessário do processo ou uma consequência necessária do direito à tutela judicial. Ainda mais claramente o expunha GOLDSCHMIDT ao definir o conceito de processo do ponto de vista empírico, como procedimento encaminhado à consecução da coisa julgada".
} 
d) do interesse do Estado na fragilização da coisa julgada, que utiliza o Judiciário para a rolagem da sua dívida e para a discussão de decisões absurdas oriundas de procedimentos escusos ou mesmo de deficiências de defesa do aparelho estatal.

As críticas acima elencadas ganham mais relevância na medida em que o mencionado autor reconhece que a coisa julgada configura direito fundamental, pois indispensável à eficácia concreta do direito à segurança, inscrito no preâmbulo e no caput do artigo $5^{\circ}$ da Constituição Federal (BRASIL, 1988), segurança esta entendida não apenas como proteção à vida, à incolumidade física ou ao patrimônio, mas também, e principalmente, como segurança jurídica: “A coisa julgada é, assim, uma garantia essencial do direito fundamental à segurança jurídica” (GRECO, 2003, p. 105).

Para ROCHA (2009, p. 174), o fundamento político da coisa julgada reside "na necessidade de o Estado dotar de certeza a pessoa que pede resposta judicial sobre uma lide" e o seu fundamento jurídico está assentado "na necessidade de que as lides tenham fim, que não se prolonguem ad aeternum", pelo que é possível observar que o instituto ora tratado é alçado à base do direito constitucional democrático como garantia de direitos, de modo que o reconhecimento da coisa julgada pela lei maior brasileira se encontra no art. $5^{\circ}$, XXXVI, da Constituição Federal (BRASIL, 1988), que dispõe: “ $a$ lei não prejudicará o direito adquirido, o ato jurídico perfeito e a coisa julgada".

DINAMARCO (2009, p. 302) reconhece o valor constitucional da coisa julgada decorrente da origem de sua proteção: "Em si mesma, a coisa julgada não é um instituto de direito processual, mas constitucional". Fazendo um paralelo com o direito italiano, TALAMINI (2005, p. 50 e ss.) ressalta: "Na Itália, apesar do silêncio da Constituição de 1948 sobre esse ponto, alguns autores salientam o valor constitucional da coisa julgada”.

A nossa constituição, no entanto, parou nestes conceitos jurídicos indeterminados acerca do ato jurídico perfeito, do direito adquirido e da coisa julgada (ASSIS, 2006), de modo que os contornos e os limites da coisa julgada foram tratados no âmbito infraconstitucional, pelo que a matéria é tratada através da Lei de Introdução às normas do Direito Brasileiro (BRASIL, 1942) que assim dispõe em seu art. $6^{\circ}, \S^{\circ}$ : "Chama-se coisa julgada ou caso julgado a decisão judicial de que já não caiba recurso". 
O novo CPC (BRASIL, 2015) também regula a matéria, equiparando o provimento jurisdicional de mérito à lei e conceitua a coisa julgada material como qualidade especial da decisão meritória que torna o seu conteúdo imutável e indiscutível, em seus artigos 503 e 502, respectivamente.

É preciso lembrar que o artigo 467 do CPC de 1973 (BRASIL, 1973) previa: "Denomina-se coisa julgada material a eficácia, que torna imutável e indiscutível a sentença, não mais sujeita a recurso ordinário ou extraordinário”. A doutrina apontava a inexata formulação do referido artigo 467, cuja literalidade permitia a conclusão de que a coisa julgada poderia ser caracterizada como eficácia da sentença (SCARPINELLA BUENO, 2014, p. 368).

O aprimoramento terminológico decorrente do novo CPC em matéria de coisa julgada é louvável, como salienta MARINONI (2015, p. 624). Todavia, é preciso repisar a lição clássica empreendida pela doutrina processual, de modo a afastar confusões conceituais entre a coisa julgada e os efeitos das decisões judiciais.

Como ressalta ROCHA (2009, p. 173), o tratamento da coisa julgada no direito brasileiro se deu com base nas lições de Liebman, que diferenciam categoricamente os efeitos da sentença daquilo que se considera como coisa julgada, de modo que esta é entendida como uma qualidade do provimento jurisdicional assim conceituada ${ }^{5}$ : "estabilidade decorrente da impugnabilidade de decisão judicial que tenha esgotado todos os meios regularmente admitidos em direito para o seu questionamento, e que adjetiva com super-rigidez o decidido".

O destaque da coisa julgada como qualidade inerente ao provimento jurisdicional definitivo e imutável pelas vias ordinárias também é dado por JÚNIOR (2010, P. 80):

\begin{abstract}
“Ampla corrente doutrinária ensinada outrora que o principal efeito da sentença era a formação da coisa julgada. Para o CPC/73, o efeito principal da sentença é apenas "esgotar o ofício do juiz e acabar com a função jurisdicional" (art. 463), como adverte Ada Pellegrini Grinover. E a res iudicata, por sua vez, apresenta-se como uma qualidade da sentença, assumida em determinado momento processual. Não é efeito da sentença, mas qualidade dela representada pela "imutabilidade" do julgado e de seus efeitos, quando, dentro do processo, já não mais possa ser impugnada pelos remédios recursais."
\end{abstract}

\footnotetext{
5 Em relação à distinção entre efeitos da sentença e coisa julgada, ver na doutrina brasileira: DINAMARCO, Cândido Rangel, Instituições de direito processual civil, $6^{\text {a }}$ ed., vol. 3, 2009, p. 309.
} 
Por sua vez, sob o aspecto prático, a coisa julgada opera funções específicas de naturezas negativa e positiva ${ }^{6}$. A primeira pode ser entendida como a autoridade que impede o ajuizamento de novas demandas com o mesmo objeto e, para tanto, a legislação processual trata de prever mecanismos de repelência previstos nos arts. 337, VII, $\S^{\circ}$ e $485, \mathrm{~V}, \mathrm{CPC} / 15$ (BRASIL, 2015).

A função positiva da coisa julgada se refere à vinculação da atuação dos juízes em processos futuros a tomar como premissa a situação jurídica definida na decisão transitada em julgado sempre que ela figurar como questão prejudicial (DINAMARCO, 2016, p. 201), ou seja, uma decisão transitada em julgado, cujo objeto é um direito prejudicial (relação de parentesco, por exemplo), vincula, em consequência da função positiva, o juízo sobre o direito dependente (direito aos alimentos, por exemplo).

Os efeitos da sentença, por sua vez, correspondem aos resultados efetivamente produzidos por este provimento e não se confundem, portanto, com a característica adquirida por meio da coisa julgada e que se refere à impossibilidade de alteração do provimento jurisdicional, senão através de mecanismos excepcionais e limitados.

Sobre este tema assevera PIGNATARI (2014, p. 38): “Nesta esteira, efeitos correspondem à ideia de consequência do comando emitido na decisão, provocando alterações no mundo dos fatos", alterações estas que dependem do conteúdo de cada provimento jurisdicional, se declaratório, constitutivo ou condenatório, por exemplo.

Esclarecendo sobre esta distinção entre os efeitos da sentença e a coisa julgada material, DINAMARCO (2016, p. 201) também remete à lição de Liebman do ano de 1935 (Efficacia ed autoria dela sentenza), “ao esclarecer que a coisa julgada não é um efeito ou uma eficácia da sentença, mas sua peculiar autoridade, consistente na imutabilidade de seus efeitos".

Para o bom entendimento do tema tratado neste trabalho, também se faz necessário diferenciar efeitos do que se denomina por eficácia das decisões judiciais.

Como já foi mencionado acima, os efeitos se consubstanciam nas consequências derivadas do provimento jurisdicional. A eficácia trata exclusivamente da aptidão potencial das decisões para a produção de efeitos, ou seja, aquilo que

\footnotetext{
${ }^{6}$ Sobre a função negativa e a positiva da coisa julgada ver na doutrina brasileira: BARBOSA MOREIRA, José Carlos, Questões prejudiciais e coisa julgada, Rio de Janeiro, 1967, p. 64. Na doutrina italiana, ver: LIEBMAN, Enrico Tullio, Giudicato (dir. proc. civ.), in Enc. Giur., vol. XV, Roma, 1989.
} 
potencialmente poderá emanar da decisão sob o aspecto teórico, preliminar, enquanto que os efeitos já se encontram no campo da materialização.

Como mencionado no início deste trabalho, a discussão sobre os efeitos dos provimentos jurisdicionais sob os aspectos subjetivo, objetivo e temporal, remetem à natureza da decisão judicial e, portanto, ao seu conteúdo. Neste particular, partindo-se da lição de Liebman e de sua classificação ternária dos provimentos jurisdicionais, ou seja, em sentenças meramente declaratórias, condenatórias e constitutivas ${ }^{7}$, tem-se este ponto como de grande importância para a análise que ora se empreende, tendo em vista a consideração de que as duas primeiras categorias de sentenças jurisdicionais importam em efeitos ex tunc.

Todavia, o enquadramento das decisões tomadas em controle de constitucionalidade em cada segmento desta classificação ternária ainda é de certa forma controversa PIGNATARI (2014, p. 67).

Com base na doutrina clássica alemã, que classificava os efeitos das sentenças em dois grupos: os principais, que derivam diretamente da tutela jurisdicional concedida no provimento (vide a classificação ternária mencionada acima); e os efeitos de fato (ou privatísticos secundários ou colaterais) que ocorrem independentemente da vontade do juiz e os denominados de reflexos, que geravam impactos nas relações jurídicas de terceiros, a doutrina processual brasileira produziu diversas classificações sob as influências de Calamandrei e Liebman.

Calamandrei foi responsável pela identificação de dois efeitos derivados do julgado, denominando de efeitos do julgado os que decorrem diretamente do conteúdo da decisão e outros de por força de lei e independentemente da vontade do juiz aqueles que podem derivar do provimento jurisdicional, tudo com base nas noções de ato jurídico para os primeiros e de fatos jurídicos para os segundos. Prossegue identificando os primeiros como internos e os segundos de externos (PIGNATARI, 2014, p. 46-47).

Os efeitos externos reconhecidos por Calamandrei foram chamados de efeitos secundários da sentença por Liebman e se caracterizam por decorrerem da própria lei, serem acessórios e derivados dos efeitos principais da sentença, e por não fazerem parte do objeto da decisão judicial (PIGNATARI, 2014, p. 50).

\footnotetext{
${ }^{7}$ Ver Liebman: Efficacia e autorità della sentenza (ed altri scritti sulla cosa giudicata), Milão : Giuffré, 1962; ID., Eficácia e autoridade da sentença e outros escritos sobre a coisa julgada, $4^{\circ}$ ed., com notas e observações de GRINOVER, Ada Pellegrini, Rio de Janeiro: Forense, 2006.
} 
Nesta categoria se encontra a previsão constante do art. 52, X, da Constituição Federal de 1988 (BRASIL, 1988) de suspensão da execução, pelo Senado Federal, de lei declarada inconstitucional pelo STF, cuja decisão não goza de eficácia vinculante imediata perante terceiros, denominada de erga omnes.

Todavia, os denominados efeitos reflexos, que se projetam sobre relações jurídicas de interesses de terceiros, também se revelam deveras importantes para o presente trabalho, uma vez que a análise sobre o controle de constitucionalidade empreendido pela via concreta e incidental pelo STF, com a redação atual do Novo Código de Processo Civil, poderá impactar em provimentos jurisdicionais já acobertados pelo manto da coisa julgada por meio de instrumento processual próprio.

Diante do ora tratado, é possível concluir que a coisa julgada não goza de efeitos próprios, mas se aproveita dos efeitos gerados a partir de cada provimento jurisdicional, efeitos estes que podem se prolongar para além do objeto e das partes envolvidas no processo no qual a decisão foi proferida.

Neste particular, cabe tratamento especial à coisa julgada constitucional formada em controle difuso, especialmente no referente aos seus limites objetivos, subjetivos e temporais, considerando-se as introduções do novo código de processo civil.

\section{A COISA JULGADA INCONSTITUCIONAL}

Críticas são endereçadas à locução "coisa julgada inconstitucional” pela doutrina constitucionalista, uma vez que "não se pode considerar haver julgamento válido e subsistente contra a Constituição, pois o juiz busca a fonte de sua competência nesta Lei Suprema e sobre ela constrói os seus julgados” (ROCHA, 2009, p. 181); além disto, em função de que é necessário reconhecer que aquilo que é apto a afrontar a constituição é o conteúdo da sentença e não a coisa julgada em si (PIGNATARI, 2014, p. 361), uma vez que esta tem assento na própria constituição.

Como dito, o fundamento da coisa julgada reside nos alicerces do Estado Democrático de Direito e sem o adequado respeito a ela, "os litígios jamais acabarão, renovando-se, a todo instante, sob o pretexto de ofensa a este ou aquele princípio constitucional" (ASSIS, 2006), pelo que o desrespeito à coisa julgada importa em 
menosprezo à segurança jurídica e à boa-fé, impactando diretamente na certeza necessária à definição do padrão de conduta dos indivíduos.

Sob esta perspectiva, o tratamento da coisa julgada e a sua desconstituição em face de reconhecida inconstitucionalidade dos fundamentos da decisão judicial passada em julgado, implica na compatibilização entre os Princípios da Segurança Jurídica na sua vertente de intangibilidade da coisa julgada - e da Inafastabilidade da Jurisdição com o Princípio da Constitucionalidade, este entendido pela imposição da obrigação de garantia da constituição, como “consequência da força normativa $e$ vinculativa da Constituição enquanto Lei Fundamental a ordem jurídica e por ser enunciado a partir do contraposto da inconstitucionalidade" (JÚNIOR. 2001).

Por este último princípio, os atos jurisdicionais recebem a sua validade da própria constituição e a mantém sob a condição de serem conformes com ela: "São duas questões: uma, o conflito entre segurança jurídica e justiça; outra, o conflito com a Constituição" (SILVA, 2009, p. 23).

Com base na Teoria da Nulidade das Leis Inconstitucionais ${ }^{8}$, aqui incluídos os atos judiciais, que implica na consideração de que tais atos são nulos, írritos, parte da doutrina defende que o vício da inconstitucionalidade impede conformação do ato judicial e, consequentemente, a formação da coisa julgada, pois para que esta qualifique o julgado, conferindo-lhe imutabilidade, há necessidade de implementação da condição jurídica prévia de adequação da atividade jurisdicional estatal aos ditames constitucionais. Isso implica concluir que a ninguém, muito menos ao agente estatal, é autorizada a atuação contra a constituição, conforme defende ROCHA (2009, p. 171):

\footnotetext{
“A Constituição dita a verdade institucional e jurídica. Dela não se poderá afastar para a prática de qualquer ato estatal, aí incluído o judicial terminativo de um processo. Não há verdade jurídica contra a Constituição. Não se produz direito contra a Constituição. Não há competência estatal outorgada para a prática de qualquer ato que contrarie a Constituição".
}

\footnotetext{
${ }^{8}$ Sobre a matéria é importante a ressalva (CANOTILHO, 2013, p. 373): "No Brasil, jamais se aceitou a concepção de que a nulidade da lei importaria na eventual nulidade de todos os atos que com base nela viessem a ser praticados. Embora a ordem jurídica brasileira não disponha de preceitos semelhantes aos constantes do $§ 79$ da Lei do Bundesverfassungsgericht, que prescreve a intangibilidade dos atos não mais suscetíveis a impugnação, não se deve supôr que a declaração de nulidade afeta todos os atos praticados com fundamento na lei inconstitucional. É verdade que o nosso ordenamento não contém regra expressa sobre o assunto, aceitando-se, genericamente, a ideia de que o ato fundado em lei inconstitucional está eivado, igualmente, de iliceidade. Concede-se, porém, proteção ao ato singular, em homenagem ao princípio da segurança jurídica, procedendo-se à diferenciação entre o efeito da decisão no plano normativo (Normebene) e no plano do ato singular (Einzelaktebene) mediante a utilização das chamadas fórmulas de preclusão".
} 
Portanto, esta colisão de princípios, para ROCHA (2009), implica na prevalência do Princípio da Constitucionalidade, o que importa na não convalidação do julgado pelo decurso do tempo, abrindo, consequentemente, a possibilidade de sua rediscussão a qualquer momento e sem a exigência de instrumento processual específico:

\footnotetext{
“Como nulidade é sempre alegável, mais ainda aquela cujo vício seja o da inconstitucionalidade, que é, portanto, inconvalidável, há que se considerar como, processualmente, proceder-se à impugnação do julgado fundamentado em norma declarada inválida, nos termos acima descritos. Em princípio, tanto não se dará no mesmo processo no qual se tenha dado o agravo constitucional, mas em outro."
}

Entretanto, esta autora pondera e ressalva que, caso o desfazimento da coisa julgada acarrete grave dano a outros princípios constitucionais, tais como a dignidade da pessoa humana ou liberdade, deve-se evitar o resultado nulificador (ROCHA, 2009, p. 188).

Apesar desta posição, a tese da relativização da coisa julgada não prepondera no Brasil, especialmente em face da proteção da confiança e da certeza, necessárias à convivência social harmônica e ao Estado Democrático de Direito. Logo, a rediscussão da sentença que tenha afrontado a constituição por meio da ação rescisória está sujeita aos requisitos legais previstos na legislação ordinária, dentre eles o prazo decadencial, de forma que é possível concluir que, ultrapassado este limite temporal, resta prejudicado o ataque à decisão de conteúdo inconstitucional, conforme concluiu o STF no julgamento do Recurso Extraordinário no 730.462-SP (BRASIL, 2015).

Portanto, apesar da doutrina e da jurisprudência brasileiras reconhecerem a importância do Princípio da Constitucionalidade, este é ponderado em face do direito fundamental à segurança jurídica e à garantia da tutela jurisdicional, de modo que, mesmo a coisa julgada assentada em pressuposto legal inconstitucional não poder ser atacada a qualquer tempo - aqui não se está a tratar das nulidades que impedem a formação da própria coisa julgada, como a ausência de citação, por exemplo -, mas sim pela via da ação rescisória no prazo atualmente estabelecido no art. 975, do novo código de processo civil (BRASIL, 2015). 


\title{
4. CONTROLE DifUSO DE CONSTITUCIONALIDADE REALIZADO NO NOVO CÓDIGO DE PROCESSO CIVIL
}

Pretende-se com este trabalho avaliar as disposições previstas no novo CPC (BRASIL, 2015), pertinentes aos efeitos do controle difuso de constitucionalidade exercido pelo STF, tendo em vista o disposto no art. 525, $\S \S 12$ e 15 in verbis:

\begin{abstract}
Art. 525. (...) § 12. Para efeito do disposto no inciso III do § 1o deste artigo, considera-se também inexigível a obrigação reconhecida em título executivo judicial fundado em lei ou ato normativo considerado inconstitucional pelo Supremo Tribunal Federal, ou fundado em aplicação ou interpretação da lei ou do ato normativo tido pelo Supremo Tribunal Federal como incompatível com a Constituição Federal, em controle de constitucionalidade concentrado ou difuso. (...) $\$ 15$. Se a decisão referida no $\$ 12$ for proferida após o trânsito em julgado da decisão exequenda, caberá ação rescisória, cujo prazo será contado do trânsito em julgado da decisão proferida pelo Supremo Tribunal Federal. (g. n.)
\end{abstract}

A inovação legislativa sobre os efeitos da decisão de controle de constitucionalidade tomada pela via concreta e sua repercussão sobre a coisa julgada formada em outros processos com a reabertura do prazo da rescisória, bem como as discussões acerca da necessidade de avaliação dos impactos destas inovações sobre o disposto no art. 52, X, da Constituição Federal vigente (BRASIL, 1988), importam em sensíveis temas no âmbito da conexão entre direito constitucional e o processo civil.

Assim, a seguir serão abordados recentes julgados do STF sobre as matérias e o entendimento da doutrina processual brasileira acerca das consequências da alteração legislativa acima, seja no que se refere aos efeitos do provimento jurisdicional do STF sobre os demais casos judicializados e que demandam discussão sobre a lei declarada inconstitucional, bem como acerca da necessidade de composição dos princípios constitucionais da Constitucionalidade e da Intangibilidade da Coisa Julgada para a aplicação do disposto no §15, do art. 525, do novo CPC (BRASIL, 2015).

\subsection{Os efeitos reflexos das decisões em controle de constitucionalidade realizado pelo Supremo Tribunal Federal}

O STF, no julgamento do Recurso Extraordinário no 730.462 - SP (BRASIL, 2015), tratou dos efeitos do controle de constitucionalidade realizado pelos seus 
próprios julgados, especialmente sobre as eficácias normativa e executiva desta espécie de provimento e, em tempo, rechaçou a possibilidade desses julgados influírem diretamente sobre a coisa julgada formada anteriormente, por meio da restrição da eficácia executiva dos provimentos de matéria constitucional em apreço, a despeito do reconhecimento da Teoria da Nulidade dos Atos Inconstitucionais, conforme segue:

\begin{abstract}
"A afirmação da constitucionalidade ou inconstitucionalidade da norma no âmbito da ação de controle concentrado (ADI ou ADC) simplesmente reconhece a sua validade ou a sua nulidade, gerando, no plano do ordenamento jurídico, a consequência (que se pode denominar de eficácia normativa) de manter ou excluir a referida norma do sistema de direito. Todavia, dessa sentença de mérito decorre também o efeito vinculante, consistente em atribuir ao julgado uma qualificada força impositiva e obrigatória em relação a supervenientes atos administrativos ou judiciais. É o que se pode denominar de eficácia executiva ou instrumental, que, para efetivar-se, tem como mecanismo executivo próprio, embora não único, a reclamação prevista no art. 102, I, "l”, da Carta Constitucional." (g. n.)
\end{abstract}

A eficácia normativa derivada do comando declaratório da sentença que reconhece a inconstitucionalidade tem efeito retroativo apto a retirar do mundo jurídico a norma atacada, especialmente em face da teoria da nulidade das leis e atos inconstitucionais. Todavia, os atos anteriores a esta declaração não se submetem à eficácia executiva (vinculante) desses julgados, uma vez que o STF reconheceu a limitação no alcance desta eficácia no âmbito deste tipo de decisão: “o termo inicial da vinculação é a data de publicação do acórdão e não a origem da norma. Isso se dá porque o efeito vinculante não decorre da validade ou invalidade da norma, mas da sentença que a aprecia" (PIGNATARI, 2014, p. 293).

Tratam-se, pois, de decisões com efeito vinculante prospectivo, ou seja, só há obrigatoriedade de observância do precedente pelas demais instâncias do Judiciário a partir do momento em que o STF atuar sobre determinado fundamento constitucional.

Ademais, a coisa julgada anterior, cuja sentença se fundamentou na lei declarada inconstitucional, só pode ser atacada através dos mecanismos legais previstos na constituição federal ou na legislação infraconstitucional ${ }^{9}$. No primeiro caso, por meio

\footnotetext{
${ }^{9} \mathrm{O}$ mesmo ocorre sob a égide do sistema constitucional português, conforme acentua MIRANDA (2008, p. 289-291): "I - A declaração de inconstitucionalidade com força obrigatória geral de qualquer norma não afecta os casos julgados. Quer dizer: não modifica, nem revoga a decisão de qualquer tribunal transitada em julgado que a tenha aplicado, nem constitui fundamento da sua nulidade ou de recurso extraordinário de revisão. (...) O fundamento último da regra não se encontra, porém, só num princípio da separação dos poderes. Decorre de um princípio material - a exigência de segurança jurídica. A
} 
da Reclamação Constitucional prevista no art. 102, I, “l”, da carta republicana (BRASIL, 1988) e na segunda hipótese por intermédio da Ação Rescisória que, ao tempo do julgado do STF ora abordado deveria ser enquadrada no art. 485, V, do CPC/73 (BRASIL, 1973), que tratava da violação literal de lei.

Atualmente o novo CPC (BRASIL, 2015) também prevê hipótese semelhante de cabimento de ação rescisória em seu art. 966, inciso V. Todavia, em redação mais acertada, o legislador substituiu o termo "lei" por "norma jurídica", expurgando qualquer dúvida sobre o cabimento deste remédio autônomo contra decisão judicial violadora direta de preceito normativo em sentido amplo (regulamento, lei etc.).

O fato é que o julgado em referência não abordou os efeitos do controle difuso de constitucionalidade sobre outros interesses jurídicos em discussão em outras demandas judiciais e com o envolvimento de partes diversas. Ou seja, a discussão se dá no âmbito da possibilidade de enquadramento destas situações na eficácia vinculativa dos provimentos do STF ou meramente nos denominados efeitos reflexos dos quais tratamos acima, tema este abordado pelo STF no julgamento da Reclamação 4335-AC (BRASIL, 2014), como será exposto adiante.

\subsection{O cabimento de ação rescisória fundada em controle difuso de constitucionalidade realizado pelo Supremo Tribunal Federal (art. 525, §15, NCPC)}

O novo CPC inovou legislativamente ao estabelecer a possibilidade de ajuizamento de ação rescisória em caso de julgamento em controle de constitucionalidade realizado pelo STF pela via difusa sem sequer condicionar este cabimento a uma decisão proferida pelo plenário do Supremo.

Esta inovação nos remete a reflexão acerca dos efeitos do controle de constitucionalidade realizado pelo Supremo e sobre a aproximação progressiva entre os controles concentrado e difuso que vem se observando no Brasil, fenômeno destacado pela Teoria da Abstrativização do Controle Difuso de Constitucionalidade, que traz ao

estabilidade do direito tomado certo pela sentença insusceptível de recurso ordinário é, igualmente, a dos direitos e interesses que declara. (...) III - A ressalva dos casos julgados não obsta à proteção a dar ao particular atingido pela norma declarada inconstitucional, que poderá propor uma acção de responsabilidade com base no art. 22. ${ }^{\circ}$ da Constituição ou, se for o caso disso, interpor recurso extraordinário de revisão da sentença transitada". 
debate acerca a sustentação do disposto no art. $52, \mathrm{X}^{10}$, da Constituição (BRASIL, 1988).

O STF, todavia, no julgamento da Reclamação 4335/AC (BRASIL, 2014), discutiu se uma decisão tomada em sede de controle difuso poderia lastrear reclamação constitucional contra decisão judicial com entendimento diverso, ou seja, se esta espécie de provimento gozaria de efeito vinculante (eficácia erga omnes) como as decisões tomadas em controle concentrado, conforme resumo do relator:

\begin{abstract}
"A divergência entre os votos que, de um lado, conheceram e deferiram a reclamação e os que, de outro, não a conheceram ou a julgaram improcedente, ficou polarizada em torno de um núcleo central, relativo ao sentido e alcance que se deve conferir, ao dispositivo do art. 52, X da Constituição, que arrola entre as competências privativas do Senado Federal a de "suspender a execução, no todo ou em parte, de lei declarada inconstitucional por decisão definitiva do Supremo Tribunal Federal" (CRFB/1988, art. 52, X). Segundo o voto do Ministro relator, "é possível, sem qualquer exagero, falar-se aqui de uma autêntica mutação constitucional em razão da completa reformulação do sistema jurídico e, por conseguinte, da nova compreensão que se conferiu à regra do art. 52, X, da Constituição de 1988", o que propiciaria a eficácia erga omnes das decisões do STF, reconhecendo a inconstitucionalidade, mesmo quando proferidas no âmbito do controle incidental. Os votos contrários, por sua vez, negam a ocorrência dessa mutação, insuscetível de se operar por exclusiva obra pretoriana”.
\end{abstract}

Ora, no caso em comento, tendo prevalecido o voto dissidente do Min. Teori Zavascki, o STF reconheceu não haver o art. 52, X, da CF/88 sofrido mutação constitucional e, de conseguinte, que os julgados do STF em controle concreto-difuso não operam efeitos vinculantes erga omnes, posto que o mencionado dispositivo constitucional ainda se presta a dar esta eficácia às decisões sobre normas desconformes ao texto constitucional, mediante decisão política do Senado Federal.

Isto porque, segundo este entendimento, se estaria tratando, na verdade, da denominada força expansiva dos precedentes do Supremo tomados em controle difuso que, apesar de não vincular, operam efeitos sobre outros processos em se que discutem

\footnotetext{
10 Esta teoria entende que o disposto no artigo 52, X, da CF/88 (BRASIL, 1988) sofreu mutação constitucional, de modo que ao Senado caberia apenas a obrigação de dar publicidade a estas decisões: "Parece legítimo entender que a fórmula relativa à suspensão de execução da lei pelo Senado Federal há de ter simples efeito de publicidade. Dessa forma, se o Supremo Tribunal Federal, em sede de controle incidental, chegar à conclusão, de modo definitivo, de que a lei é inconstitucional, essa decisão terá efeitos gerais, fazendo-se a comunicação ao Senado Federal para que publique a decisão no Diário do Congresso. Tal como assente, não é (mais) a decisão do Senado que confere eficácia geral ao julgamento do Supremo. A própria decisão da Corte contém força normativa" MENDES (2013, p. 1099-1100).
} 
relações jurídicas fundadas no preceito constitucional sobre o qual julgou a corte máxima brasileira.

Este movimento na teoria constitucional brasileira faz parte, segundo o doutrinador e ministro do Supremo Teori Zavascki, de um amplo movimento transnacional de aproximação entre os regimes civil law e common law que opera desdobramentos práticos, conforme relatado no voto proferido no julgado ora avaliado, da Rcl 4335/AC ${ }^{11}$ (BRASIL, 2014).

O efeito expansivo dos julgados do Supremo não se dá apenas com a aplicação do art. 52, X, CF/88, mas pode ser observado através de várias mudanças que vêm se operando no âmbito da legislação processual nacional nas últimas décadas. Dentre elas, destacou o Min. Zavascki em seu voto (BRASIL, 2014), a EC ${ }^{\circ}$ 45/2004 que introduziu em nosso ordenamento a possibilidade de edição das súmulas vinculantes e a repercussão geral como requisito de admissibilidade do Recurso Extraordinário.

Além destas alterações legislativas, em mais uma demonstração da importância deste efeito, a jurisprudência do STF passou a entender cabível a possibilidade de modulação dos efeitos dos julgados realizados em controle incidental, estendendo a aplicação do art. 27, da Lei 9868 (BRASIL, 1999), de forma que é preciso reconhecer que o ordenamento jurídico brasileiro vem se aproximando cada vez mais da cultura do stare decisis em que o respeito ao precedente é fundamental.

A influência do provimento jurisdicional do STF em controle de constitucionalidade na modalidade difuso-incidental sobre outros processos, previsto no art. 525, §15, do NCPC (BRASIL, 2015), pode ser enquadrado como mais um efeito expansivo desta espécie de provimento e dá prosseguimento a este movimento de aproximação com o sistema da common law.

Todavia, este novo dispositivo não pode ser considerado como um prestígio à coisa julgada, pois importa exceção deveras elástica do princípio da intangibilidade da coisa julgada, conforme assevera MARINONI (2016, p. 707): “ação rescisória com base em posterior declaração de inconstitucionalidade é uma macro exceção à

\footnotetext{
${ }^{11}$ Segundo o relator: "a evolução do direito brasileiro em direção a um sistema de valorização dos precedentes judiciais emanados dos tribunais superiores, aos quais se atribui, cada vez com mais intensidade, força persuasiva e expansiva em relação aos demais processos análogos. Nesse ponto, o Brasil está acompanhando um movimento semelhante ao que também ocorre em diversos outros países que adotam o sistema da civil law, que vêm se aproximando, paulatinamente, do que se poderia denominar de cultura do stare decisis, própria do sistema da common law"
} 
intangibilidade da coisa jugada material", de forma que este dispositivo é "irremediavelmente inconstitucional".

\subsection{O problema da declaração de inconstitucionalidade e o decurso do tempo.}

\section{O novo prazo para o ajuizamento da rescisória e a segurança jurídica.}

A inovação legislativa ora tratada merece ainda esclarecimentos sobre seus contornos pela doutrina e pelos tribunais, isto em função de que, da leitura do art. 525, $\S 15$ (BRASIL, 2015), é possível concluir que o legislador criou um novo e independente prazo para o ajuizamento da ação rescisória: "contado do trânsito em julgado da decisão proferida pelo Supremo Tribunal Federal”.

Esta conclusão, todavia, deve ser tomada com toda cautela, sob pena de grave afronta ao princípio constitucional da segurança jurídica e da intangibilidade da coisa julgada, sob o pretexto de se primar pela justiça, mesmo porque já há ataques diretos ao texto deste dispositivo, especialmente pelo fato de permitir a rediscussão de casos a qualquer tempo:

\footnotetext{
"Essas normas são claramente inconstitucionais, pois, em afronta ao mínimo de segurança jurídica necessário à vida em sociedade, dão ensejo à impugnação da decisão muitos anos após o trânsito em julgado, sem limitar o cabimento da ação rescisória à afronta de valores constitucionais de extrema relevância (infra, n. 170)" (DINAMARCO, 2016, p. 222) (g. n.)
}

Neste mesmo sentido, MARINONI (2016, p. 708-709) assevera que "os juizes e tribunais não devem aplicar o $\$ 15$ do art. 525 do CPC de 2015, dada a sua inescondivel e insuperável inconstitucionalidade" uma vez que "isso significaria violação da garantia constitucional da coisa julgada material”, tendo o STF já se manifestado em caso análogo (RE 590.809, julgado em 22.10.2014).

Ademais, outros argumentos sustentam que a melhor interpretação do novel dispositivo é aquela tendente a limitar no tempo a sua aplicação porque, apesar do julgado do Supremo possuir forma persuasiva (eficácia expansiva), consoante já se mencionou, este não configura requisito essencial para o ajuizamento da ação rescisória, uma vez que a inconstitucionalidade, estando presente, dá ensejo ao ajuizamento da ação rescisória por violação literal de norma jurídica. 
Assim, apesar do pronunciamento da Corte Suprema funcionar como reforço ao argumento da inconstitucionalidade, é de se destacar que o cabimento da rescisória já estava configurado em função da simples afronta ao texto constitucional, não sendo o novo paradigma do STF essencial para tanto (PIGNATARI, p. 394).

Além disto, o prazo previsto no art. 975, NCPC é decadencial e, portanto, uma vez escoado implica no perecimento do próprio direito da parte de rediscutir o julgado. Assim, há quem defenda que a melhor interpretação do dispositivo em comento seria aquela que o entende como hábil, exclusivamente, a prolongar o prazo estabelecido em lei a partir do trânsito em julgado da sentença que se busca rescindir ${ }^{12}$.

Apesar desta última posição conciliadora, tratar este dispositivo como apto a criar um novo prazo para o ajuizamento da ação rescisória importa em inconstitucionalidade, pois o faz incidir sobre litígios há muito resolvidos, enfraquecendo por demais a jurisdição e implicando em insegurança jurídica demasiada.

\section{CONSIDERAÇÕES FINAIS}

A possibilidade de revisão do provimento jurisdicional qualificado pela coisa julgada que repouse sobre fundamento inconstitucional, segundo entendimento posterior do STF tomado em controle difuso de constitucionalidade, deve ser tratada com extrema cautela, em prestígio os princípios da Segurança Jurídica, como decorrência do respectivo direito fundamental, e da Inasfastabilidade da Jurisdição.

Logo, assim como as tomadas em controle concentrado, as decisões tomadas em controle difuso de constitucionalidade também não operam efeitos diretos sobre a decisão judicial transitada em julgado, ainda que esta esteja assentada sobre fundamento declarado inconstitucional.

Além disto, não tendo havido mutação constitucional no art. 52, X, da Constituição da República (BRASIL, 1998), elemento que poderia fazer-se concluir que a decisão do STF em controle difuso teria efeitos erga omnes, também não se pode concluir pelo cabimento da ação rescisória fundada em declaração de

\footnotetext{
${ }^{12}$ Nesse sentido: "somente pode ser iniciado o prazo da rescisória a partir do trânsito em julgado da decisão do STF, se ainda não tiver sido extinta a pretensão rescisória cujo prazo tenha-se iniciado do trânsito em julgado da decisão exequenda". (NERY JR., 2015, p. 1309) (g. n.)
} 
inconstitucionalidade pelo STF em momento posterior ao trânsito em julgado da decisão rescindenda.

O julgamento de inconstitucionalidade pelo controle difuso sem a tomada desta decisão política pelo Senado Federal possui apenas efeitos reflexos sobre outras demandas judiciais e sobre sentenças transitadas em julgado que se lastreiem em lei declarada inconstitucional, de modo que o julgado do Supremo, nestes casos, goza apenas de eficácia expansiva e não vinculante, uma vez que o próprio pretório excelso também rejeitou, por maioria, a tese da abstrativização do controle difuso de constitucionalidade.

Por fim, o direito fundamental à segurança jurídica implica na conclusão de que o dispositivo estudado é irremediavelmente inconstitucional, uma vez que importa em afronta ao princípio da inviolabilidade da coisa julgada, conforme garantia insculpida no art. 5, XXXVI da CF/88 (BRASIL, 1988). Aceitá-lo é menosprezar a importância da coisa julgada para o Estado de Direito, admitindo que ela "sempre será provisória e sujeita a condição resolutiva, o que é uma contradição" (MARINONI, 2016, p. 711).

\section{REFERÊNCIAS}

ASSIS, Araken de. Eficácia da coisa julgada inconstitucional. Disponível em: http://amdjus.com.br/doutrina/civil/170.htm. Acesso em: 28.07.2016.

BARBOSA MOREIRA, José Carlos. Questões prejudiciais e coisa julgada. Rio de Janeiro, 1967.

. Algumas considerações sobre coisa julgada no Novo Código de Processo Civil brasileiro: limites objetivos e eficácia preclusiva in Revista de processo comparado, ano 1, vol. 2, 2015.

BRASIL. Constituição da República Federativa do Brasil de 1988. Disponível em http://www.planalto.gov.br/ccivil_03/Constituicao/Constituicao.htm. Acesso em 25/07/2016.

Decreto-Lei $\mathbf{n}^{0}$ 4.657, de 04 de setembro de 1942. Disponível em http://www.planalto.gov.br/ccivil_03/decreto-lei/Del4657compilado.htm. Acesso em 25/07/2016.

Emenda Constitucional $n^{\circ}$ 45, de 30 de dezembro de 2004. Disponível em http://www.planalto.gov.br/ccivil_03/Constituicao/Emendas/Emc/emc45.htm. Acesso em 31.07.2016. 
. Lei $\mathbf{n}^{0}$ 5.869, de 11 de janeiro de 1973. Disponível em

http://www.planalto.gov.br/ccivil_03/leis/L5869.htm. Acesso em 29/07/2016.

Lei $\mathbf{n}^{\circ}$ 9.868, de 10 de novembro de 1999. Disponível em

http://www.planalto.gov.br/ccivil_03/leis/L9868.htm. Acesso em 31/07/2016.

Lei $\mathbf{n}^{0}$ 13.105, de 16 de março de 2015. Disponível em

http://www.planalto.gov.br/ccivil_03/_ato2015-2018/2015/lei/113105.htm. Acesso em 25/07/2016.

. Supremo Tribunal Federal. Reclamação Constitucional no 4.335/AC. Pleno. Diário Oficial da República Federativa do Brasil, Brasília, DF, 22 de outubro de 2014.

. Supremo Tribunal Federal. Recurso Extraordinário no 590.809/RS. Pleno.

Diário Oficial da República Federativa do Brasil, Brasília, DF, 22 de outubro de 2014.

. Supremo Tribunal Federal. Recurso Extraordinário n 730.462. Pleno. Diário Oficial da República Federativa do Brasil, Brasília, DF, 09 de setembro de 2015.

CANOTILHO, J. J. Gomes [et. al.]. Comentários à Constituição do Brasil. São Paulo : Saraiva/Almedina, 2013.

DINAMARCO, Cândido Rangel. Instituições de direito processual civil. $6^{\text {a }}$ ed., vol. 3. São Paulo : Malheiros, 2009.

Cândido Rangel; LOPES, Bruno Vasconcelos Carrilho. Teoria geral do novo processo civil. São Paulo : Malheiros, 2016.

FRANÇA. Declaração de direitos do homem e do cidadão de 1789. Biblioteca virtual de direito humanos da Universidade de São Paulo - USP. Disponível em: http://www.direitoshumanos.usp.br/ . Acesso em: 28.07.2016.

GRECO, Leonardo. Eficácia da declaração erga omnes de constitucionalidade ou inconstitucionalidade em relação à coisa julgada anterior. Revista Jurídica da Procuradoria-Geral do Distrito Federal. V. 37. 2003. Disponível em: http://revista.pg.df.gov.br/index.php/RJPGDF/article/view/12. Acesso em: 25.07.2016. p. 99-114.

JÚNIOR, Humberto Theodoro. Coisa julgada: pluralidade e unicidade (Súmula $\mathbf{n}^{\mathbf{0}}$ 401, do STJ). In Revista Magister de Direito Civil e Processual Civil. V. 35 (mar/abr). Porto Alegre : Magister. 2010.

; FARIA, Juliana Cordeiro de. A coisa julgada inconstitucional e os instrumentos processuais para seu controle. 2001. Disponível em: http://www.amprs.org.br/arquivos/revista_artigo/arquivo_1274905859.pdf. Acesso em: 30.07.2016. 
LIEBMANN, Enrico Tullio. Efficacia e autorità della sentenza (ed altri scritti sulla cosa giudicata). Milão : Giuffré, 1962.

Giudicato (dir. proc. civ.) in Enc. Giur., vol. XV, Roma, 1989.

Eficácia e autoridade da sentença e outros escritos sobre a coisa julgada, $4^{\circ}$ ed., com notas e observações de GRINOVER, Ada Pellegrini. Rio de Janeiro: Forense, 2006.

MARINONI, Luiz Guilherme; ARENHART, Sérgio Cruz; MITIDIERO, Daniel. Novo Curso de Processo Civil. vol. 2. São Paulo : Revista dos Tribunais, 2015.

Novo Curso de Processo Civil. Vol 2. 2. ed. São Paulo : Revista dos Tribunais, 2016.

MENDES, Gilmar Ferreira; BRANCO, Paulo Gustavo Gonet. Curso de direito constitucional. 8. ed. São Paulo : Saraiva, 2013.

MIRANDA, Jorge. Manual de Direito Constitucional - inconstitucionalidade e garantia da constituição. Tomo VI. 3 ed. Coimbra : Coimbra Editora, 2008.

NERY JR., NELSON; NERY, Rosa Maria de Andrade. Comentários ao Código de Processo Civil. São Paulo : Editora Revista dos Tribunais. 2015.

NIEVA-FENOLL, Jordi. Coisa Julgada. Tradução Antonio do Passo Cabral. São Paulo : Editora Revista dos Tribunais, 2016.

Organização das Nações Unidas. Declaração universal dos direitos humanos. Disponível em: http://www.dudh.org.br/declaracao/. Acesso em: 28.07.2016.

PIGNATARI, Alessandra Aparecida Calvoso Gomes. Efeitos processuais do controle judicial de constitucionalidade. 1. ed. Brasília : Gazeta Jurídica. 2014.

ROCHA, Cármen Lúcia Antunes Rocha. O Princípio da Coisa Julgada e o Vício da Inconstitucionalidade. In ROCHA, Cármen Lúcia Antunes Rocha (Org.). Constituição e segurança jurídica: direito adquirido, ato jurídico perfeito e coisa julgada. Belo Horizonte : Fórum. 2009. P. 165-191.

SCARPINELLA BUENO, Cassio. Curso sistematizado de direito processual civil. vol. 2. t. III. $4^{a}$ ed. São Paulo : Saraiva, 2014.

SILVA, José Afonso. Constituição e Segurança Jurídica. In ROCHA, Cármen Lúcia Antunes Rocha (Org.). Constituição e segurança jurídica: direito adquirido, ato jurídico perfeito e coisa julgada. Belo Horizonte : Fórum. 2009. P. 14-30.

TALAMINI, Eduardo. Coisa julgada e sua revisão, São Paulo : Saraiva, 2005. 